\title{
Influences of Philosophy and Religion
}


This page intentionally left blank 


\section{Chapter}

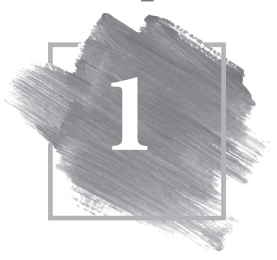

Confucianism

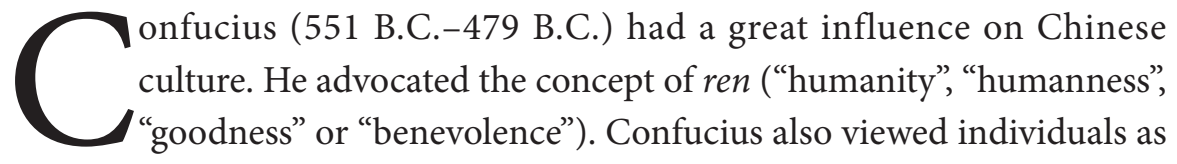
a social being whose identity derives from his interaction with the broader human community. He preached personal virtues, social order and respect for elders. Ren encompasses qualities such as self-discipline, humility, loyalty, courage and trustworthiness.

Mencius (Meng Ke or Meng Zi), born in 372 B.C. carried on Confucius' philosophy. He introduced the concept of democracy by emphasising that subjects are more important the rulers. He also advocated that one's character needed to be moulded by education. On leadership, Mencius emphasised that a wise leader is one who portrays benevolence and righteousness.

Mencius said:

"If a king shares the worries and concerns of his subjects and makes policies that enable them to live and work in peace and contentment, there is no force in existence that can stop him uniting the world." (Xu \& Zhang, 2007) 
Mencius believed that individuals are good by nature and that it is society's bad influence that causes bad moral characters. This assertion put Mencius in greater agreement with Daoism than with Confucianism. While this may seem paradoxical, Confucius himself did not provide any theory on human nature and/or elaborate why a person should be moral.

Confucianism focuses on the manner human beings ought to behave in society according to ethical or moral ways. It does not offer any explanations on the relationships between human beings and Nature. By overly emphasising on human ideals or standards, it can be argued that Confucianism has placed too much emphasis on worldly goals.

Daoists realise that human beings are only a miniscule part of the larger process of Nature. Human nature in its original pristine form can only be understood to be "so of itself" (ziran or naturalness). When human nature is aligned with Nature, order and harmony are the results.

In Daoism, self-cultivation is an important element in the search for meaning of human nature. Through self-cultivation, a Daoist seeks to return to a state of existence which is in harmony with Nature. Selfishness and ill intentions often result in disharmonies and unintended consequences which are against the natural rhythms of Nature.

From this perspective, the author postulates that Daoism had influenced Mencius' views on human nature. Mencius believed that human nature is good as it is one's innate tendencies to be benevolent, self-righteous, and proprietous. "Evil", on the other hand, is not inborn but something artificial from outside. Mencius asserted that serious efforts need to be made to return to one's original nature. This return to one's original nature is synonymous to the concept of self-cultivation in Daoism.

Confucianism focuses on moral character and ethics which encompass Five Constants or wu chang (五常). They are:

1. Ren (仁), humaneness, benevolence;

2. $Y i($ 义), righteousness, justice; 
3. $L i$ (礼), proper rite;

4. Zhi (智), knowledge, wisdom;

5. Xin (信), integrity.

Describing ren, Confucius advised "not to do to others as you would not wish done to yourself". He believed that man is kind and good by nature and should not seek wealth and status at the expense of humanity. A Confucian manager is expected to display goodness towards others and manage with kindness.

$Y i$, an ethical orientation of Confucianism, refers to the moral dispositions to do good. Individuals should have the ability to recognise what is right and good. Certain actions have to be taken for the sole reason they are right regardless of the outcomes. In this respect, managers are expected to uphold the highest standards of moral conduct.

The Confucian concept of $l i$ refers to rituals or appropriate behaviours and roles. $L i$ promotes ideals such as filial piety, faith and loyalty. Illustrating the broader application of $l i$, Confucius included broad topics such as learning, titles and governance. $L i$ regulates human interactions and etiquettes and lays the basis for the principles of social order.

Mencius added the concept of Zhi to Confucianism. Zhi refers to moral wisdom and knowing right from wrong. According to Mencius, "evil" could originate from lack of knowledge of external circumstances. Zhi is part of the growing maturation of an individual as wisdom comes with age.

Xin refers to keeping one's words and being faithful. Faithfulness is an indispensable virtue for a person. A man without faith could not be entrusted to carry out important tasks. Trust is an utmost important virtue of a leader as honest and faithful leaders are needed to maintain a harmonious organisation.

Face-saving is an important Chinese business concept which could be traced back to Confucius. Lian (face) reflects one's standing in public. Criticism from another party to cause one to lose face may jeopardise the business relationships between the parties. 
Confucius believed that education should be provided to all without any discrimination. According to him, education can make a difference to a person's character. One of the most important contributions of Confucius is that he advocated that all humans are equal and of one class.

Confucius said:

"When you see a worthy person, endeavor to emulate him. When you see an unworthy person, then examine your inner self."

Confucius advocated the five relationships model to determine rulersubject, father-son, husband-wife, elder brother-younger brother and friend-friend relationships (Figure 1). Because of the hierarchical nature, titles are important. Chinese (including Japanese and Koreans) address each other by the appropriate titles: "Mr Wong", "President Lee" or "General Ng".

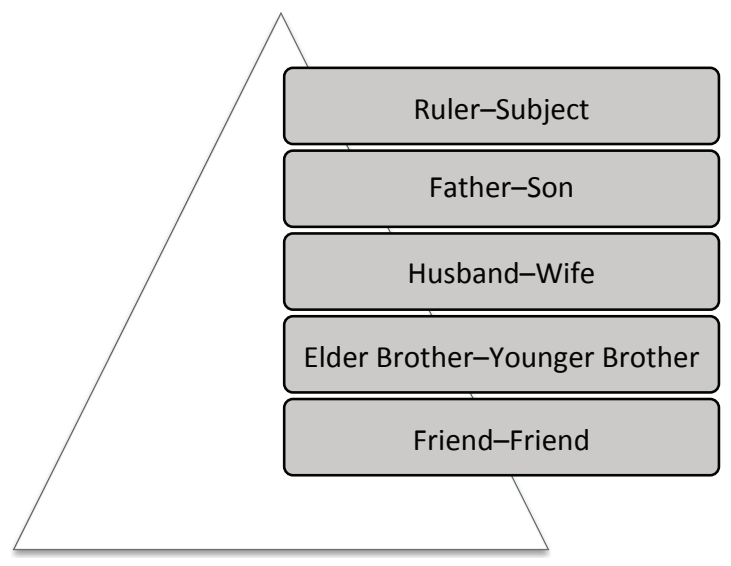

Figure 1: Confucianism on Relationships 


\section{Chapter}

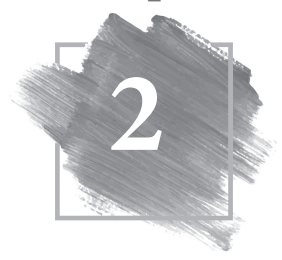

\section{Confucian Influences on Modern Management}

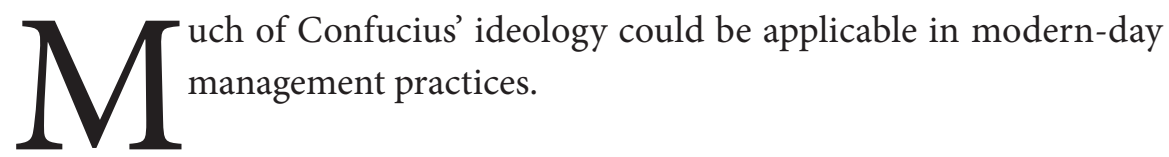

Confucius said:

1) "Success depends upon previous preparation, and without such preparation there is sure to be failure."

Businesses have to be sufficiently prepared to face the challenges in the global environment. Managers have to constantly conduct scenario planning exercises to ensure that they are adequately prepared for any downturns.

2) "If you think in terms of a year, plant a seed; if in terms of 10 years, plant trees; if in terms of 100 years, teach the people."

Confucius highlighted the importance of formulating strategies to develop competitive advantage in the business. This strategic plan is to be put into action through proper planning and organisation. 
3) "Better a diamond with a flaw than a pebble without."

Managers should value righteousness and ethical principles above profits. Their business behaviours should be governed by high moral and ethical principles.

4) "Let the ruler be a ruler, the subject a subject, a father a father, and a son a son."

The concept of absolute loyalty towards one's organisation is becoming increasingly unpopular. As employees become more educated and exposed to Western management styles, their demands for greater recognition of their work performances increase. Increased competition for talents means that the mobility rate of employees also increases. The expectation that employees work tirelessly for the good of the organisation and the nation as stated in the Analects of Confucius seems unrealistic in modern times as employees are now inclined towards work-life balance.

Mencius' contribution to modern-day management is in the area of participative management and employee autonomy. He stressed that leaders should also learn from their subordinates.

Mencius said:

"Today there are many states, all equal in size and virtue, none being able to dominate the others. This is simply because the rulers are given to employing those they can teach rather than those from whom they can learn."

Mencius also taught the need for good interpersonal relationship between superior and subordinate. Managers have to earn the support and respect of their subordinates if they wish to achieve greater goals.

Mencius quoted:

"You can never gain the Empire without the heartfelt admiration of the people in it." 
Mencius' teaching could be illustrated in the diagram below. He saw a good leader as possessing three main qualities: benevolence, servant-leadership, and humanism (Figure 2).

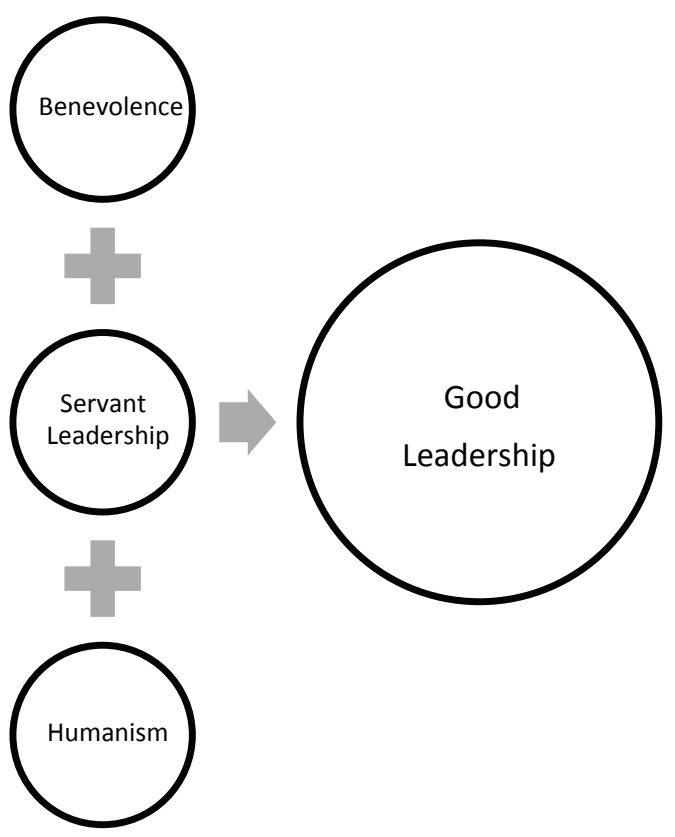

Figure 2: Qualities of a Good Leader 
This page intentionally left blank 


\section{Chapter}

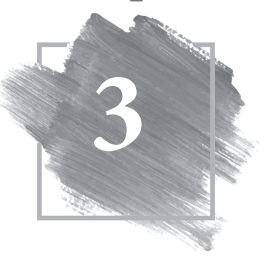

Daoism

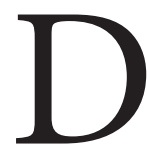

aoism was founded by Lao $\mathrm{Zi}$ (original name Li Er), a contemporary of Confucius. Lao Zi wrote the Dao De Jing, the famous Chinese philosophical text which consists of 5,000 words and 81 chapters. The concept of Dao and De are ambiguous as Lao Zi employed paradoxical languages to present his teachings. As such, Dao De Jing is open to a variety of interpretations. Dao and De have been translated as way and virtue. A number of themes in Dao De Jing are applicable to modern-day management. These include: the need to avoid conflict, the need to maintain balance and harmony, and the need to pursue inner-self cultivation.

In Daoism, balance or harmony is inherent in nature. Through multiple transformations by and within nature, things come to life. The transformation process is believed to be natural with no external forces involved. This concept has important implications in modern Chinese management as it signifies that the business environment is constantly changing and that companies need to adapt to these changes. As the environment changes, new business opportunities are also being created. 
Dao De Jing is more than just a philosophical text. It is applicable to politics, cosmology, aesthetics and ethics. Lao $\mathrm{Zi}$ believed that it is best to let nature take its course without human intervention. This is evident in the opening phrase of the first chapter of Dao De Jing:

"The truth that may be told is not the everlasting truth. The name given to a thing is not the everlasting Name."

Lao $\mathrm{Zi}$ advocated that not doing or non-action was the best way to avoid active intervention. This core principle has significant influences on Chinese management style such as motivating employees, and not controlling them.

"The sage puts himself last and becomes the first,

Neglects himself, and is preserved

Is it not because he is unselfish that he fulfils himself?"

Dao De Jing 


\section{Chapter}

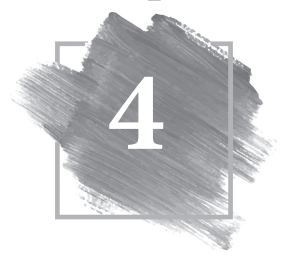

\section{Modern Daoism's Application in Business}

$\mathrm{I}$

$\mathrm{n}$ the modern world, Daoism is a global religious tradition characterised by cultural, ethnic and international diversity. Daoist followers value wuzhi (non-knowing), and at the same time, seek to resolve huo (perplexity). The Dao (Way) is formless, nameless, mysterious, and unknowable. While unknowable, the Dao may be experienced and pervades the world and being. This perplexity leads one to commit to search for deeper understanding.

Daoism is often regarded as both philosophy and religion. The philosophical aspect of Daoism is related to Dao De Jing (Scripture of the Dao and Inner Power) and Zhuangzi (Book of Master Zhuang). The practice of wu wei (non-action) reflects self-transformation that is inherent within things, as all natural processes are perceived to be linked to harmony and balance. This concept of $w u$ wei has often been criticised as being overly simplistic and impractical in modern-day management theory. Transformation occurs naturally with no external force involved. Transformation also means that things are never absolute and constantly changing. Another principle of Daoism is reversion which implies that the opposite things can occur. 
In Daoism, the two polar energies of Ying and Yang represent the principle of natural and complementary forces. They are opposite forces that fit together seamlessly and work together in harmony. Ying and Yang are not static as the balance ebbs and flows between them. This is implied in the curvature line where they meet. The concept of Ying and Yang is also applicable to business (Figure 3).

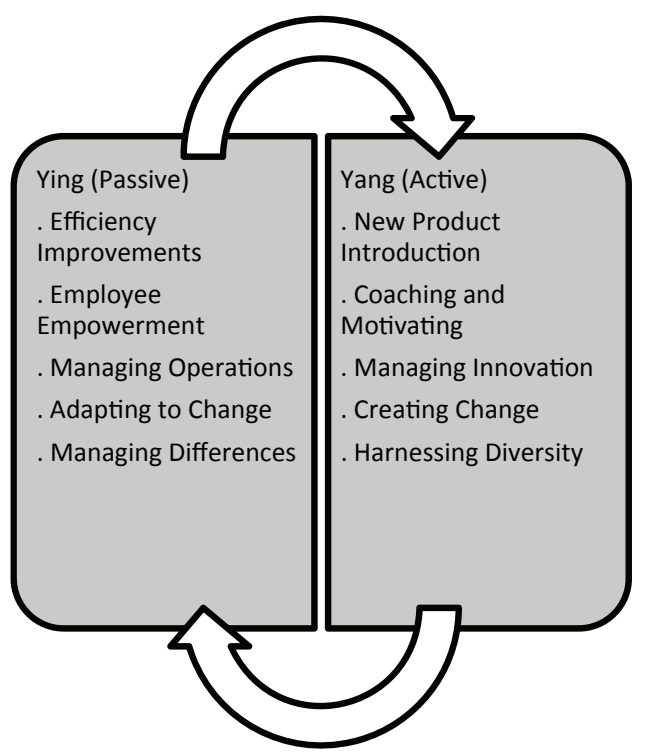

Figure 3: Daoism for Business

The influence of Daoism is prevalent in contemporary Chinese businesses (Tian, 2008; Xing and Sims, 2011). The perplexed situation of mingling philosophies and religions contributes much to the development of China's management theory today (Wang et al., 2012). The principle of transformation means that alternatives and other opportunities are available and that things are never absolute (Cheung and Chan, 2005).

The principle of reversion advocates a reverse action and using a soft approach such as "give in order to take, and follow in order to lead" (Cheung and Chan, 2008). 
"When one is about to take an inspiration, he is sure to make a (previous) expiration; when he is going to weaken another, he will first strengthen him; when he is going to overthrow another, he will first have raised him up; when he is going to despoil another, he will first have made gifts to him: this is called 'Hiding the light (of his procedure)'.

The soft overcomes the hard; and the weak the strong.

Fishes should not be taken from the deep; instruments for the profit of a state should not be shown to the people."

Dao De Jing

Loyalty is not important in Daoism as it advocates following the Way rather than following instructions of a company's boss. This is unlike Confucianism which places great importance on loyalty, order and respect. In Daoism, living in simplicity and in tune with nature is more important. To Daoist adherents, the best form of governance is the one that governs the least. In modern management context, this relates to empowerment and delegation of duties and responsibilities to subordinates. The humanistic approach of Daoism opens up new perspectives in leadership studies and could provide complementary answers to Western models which are often empirically based, but do not provide explanations of relational processes.

Lao Zi said:

"If people are difficult to govern, it is because those in authority are too fond of action."

Modern Chinese management style is a synthesis of Confucianism, Daoism, Buddhism and Occidental philosophies. This is a result of advancements in technologies and globalisation of Asian economies as business people and academicians become more exposed to other cultures and adopt those management practices that offer the best results and solutions to them. 
This page intentionally left blank 


\section{Chapter}

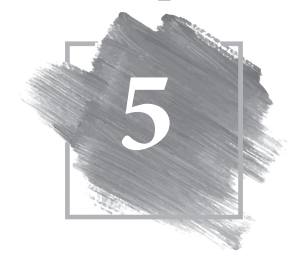

\section{Buddhism}

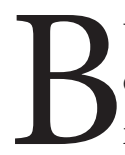

uddhism originated from India and shares many of the Hindu concepts of karma and samsara. The founder was a young prince from Nepal named Siddhartha Gautama. He left a life of luxury to experience human sufferings. After attaining enlightenment, he was known as Buddha and spread his religious teachings of Buddhism.

According to Hinduism, karma governs the universe and the beings within it. Some beings are being elevated to the upper planetary systems while others are being lowered into the lower planetary systems. The sum total of one's good and bad deeds will determine how one will be rewarded or punished in the next life. The belief of samara or reincarnation means that there is a never ending cycle of birth, death and rebirth.

Buddhism spread into China during the Han dynasty. The popular branch of Buddhism in China is Mahayana. The Buddha that is generally worshipped is Amitabha and the Buddha which is about to arrive is Maitreya or Mi-Le Buddha. The popular Bodhisattva is Avalokiteshvara or Guanyin, also known 
as the Goddess of Mercy. Buddhism in China became popular under the Chan school which emphasized meditation. Chan Buddhism later spread to Japan where it is known as Zen Buddhism.

Today, Buddhism also plays a large role in shaping the business practices of many Asian managers. An aphorism from Buddha states:

\section{"You can only lose what you cling to."}

Buddha reminded that change is everywhere and nothing is permanent. Managers should embrace change and detach from the dogmas of old management styles.

Buddhism has its practical application in today's business world (Figure 4). Its focuses on communal harmony, ethics, teamwork, learning and development, and employers' duties are important in shaping modern management practices in the Orient.

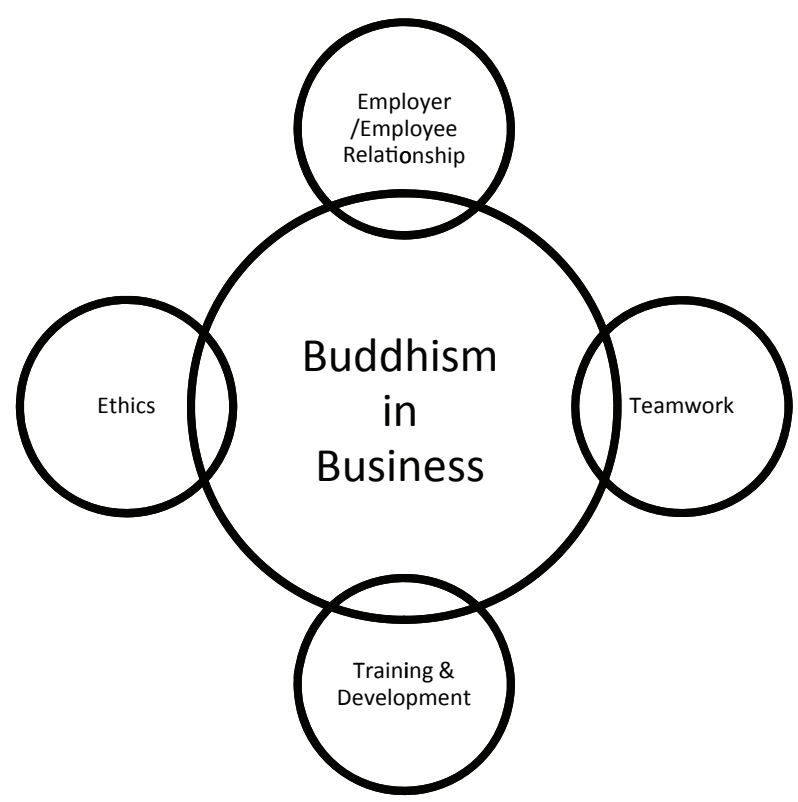

Figure 4: Buddhism in Business 
Buddhism also advocates constant learning and development. The development of others is equally important as the development of self.

Buddha said:

"Believe nothing merely because you have been told it. Do not believe what your teacher tells you merely out of respect for the teacher. But whatever, after due examination and analysis, you find to be kind, conducive to the good, the benefit, the welfare of all beings - that doctrine believe and cling to, and take it as your guide."

Buddha in his advice to Sigalaka Sutta enumerates five ways an employer should treat his employees:

1) Assigning work according to their strengths — The work assigned should be according to their mental and physical strengths. Bosses should not take advantage of their employees.

2) Giving them food and wages - Pay them accordingly to their efforts.

3) Tending them in sickness - Grant them medical leave when they are unwell.

4) Sharing with them unusual delicacies - Reward them with bonuses or other material means.

5) Granting leave at suitable times - Grant them time off for their personal matters.

Teamwork is an important concept in Buddhism. Personal sacrifice for the benefit of the team helps the organisation to pull through in times of crisis. Buddha said:

"Whoever offers sacrifice, or whoever gets others to do so - all these are following a course of merit benefiting many others." 


\section{Case of Robert Kuok}

One of the most successful Hong Kong tycoon, Robert Kuok, had mentioned that the biggest influence on his life was his devoutly Buddhist mother. She had taught him to uphold high moral standards in the process of making money and to avoid businesses that bring harm to society. Humility was also one of his greatest secret for success. He has also tried to pass on these set of values to the younger generation.

Today, the Kuok Group of companies includes the unlisted Kerry Group, Shangri La Asia and Wilmar International, which is the largest processor of palm oil in the world.

The secret of Robert Kuok's success could be found in some of his own words and the words of his business partners and competitors.

Robert Kuok once said:

"I adapt like a chameleon to the particular society where I am operating at the moment."

Robert Riley of Mandarin Oriental Hotel Group, a Shangri La competitor, said:

"He's a local everywhere he goes."

John Farrell of Coca Cola, a business partner, said:

"His whole life has been built around building networks with overseas Chinese and in China. Kerry's ability to do things fast is incredible."

As mentioned earlier, one of Robert Kuok's secrets to success was humility. He claimed that he preferred people with an inner humility than one who portrayed that he knew a lot. Someone with humility 
is ready to acknowledge his weaknesses but at the same time willing to manage them. This is the key to his political astuteness.

\section{Lao Tzu said:}

"Knowing others is wisdom, knowing yourself is Enlightenment."

While the Kuok Group of companies has significant lesser investments in Western countries as compared to China, Robert Kuok's ability of getting things done fast is an envy of other business leaders, both Eastern and Western. He has been described by Forbes as one of the shrewdest businessmen in the world.

Robert Kuok has successfully managed to integrate the qualities of Eastern and Western management styles together. Western management styles are more action oriented while Eastern management styles advocate more contemplation than fast action.

Balancing clarity with ambiguity requires a high degree of mental discipline which Robert Kuok seems to possess. Too much inquiry and deliberation result in taking too much time to make decisions. Conversely, spending too little time on inquiry and deliberation may result in the wrong decision being made (Figure 5).

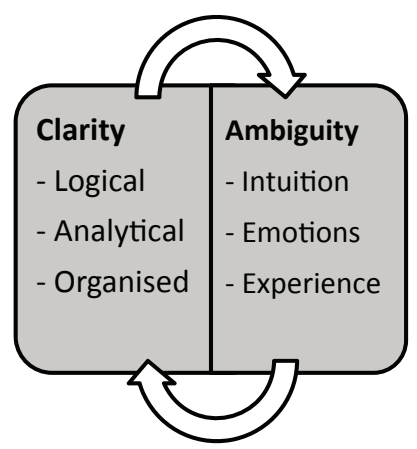

Figure 5: Clarity and Ambiguity 


\section{Case of Wahaha Beverage}

Wahaha is the largest beverage company in China with 70 production bases and 30,000 employees. The company was founded by Zong Qinghou in 1987. Chairman Zong's management style is leading with authority yet displaying benevolence. He believes that Chinese companies need strong leaders who are open-minded and tolerant to employees. Employees should be given a second chance to learn from their mistakes.

In 1999, the company established a stock option scheme to reward employees who have worked for more than one year. Employees are also given subsidies to purchase affordable houses in Hangzhou. The school fees of children of employees are also paid by the company. Chairman Zong believes that these are some ways to motivate employees to work for the company. Most employees work for the company till retirement. The company strongly emphasises on its motto "love your small family, develop our big family, and serve the country".

While Chairman Zong is ranked as one of China's richest men, he is, nevertheless, a frugal person. In an interview with BBC News in 2011, Chairman Zong claimed that he lived on USD20 a day. He said:

"My only exercise is doing market research...."

The statement reflects Chairman Zong's seriousness in his work as he seeks to balance depth and breadth in understanding the market. Too much breadth results in too little analysis done on a particular issue. Conversely, making too much in-depth analysis of a particular problem results in one ignoring alternative solutions (Figure 6).

Chairman Zong makes all the decisions. The 18 functional heads have very little decision-making capabilities. He sees himself as a paternal figure, regarding his employees as his children.

As in many entrepreneur-owned business, control of the company lies in the hands of family members. His wife and daughter help run 
some important divisions of the group business. Chairman Zong believes that hard work is the only way to get someone out of poverty and does not advocate simply giving money away. He once said in an interview:

"Donation is not charity. A true philanthropist should be able to help people in need by continuously creating social wealth."

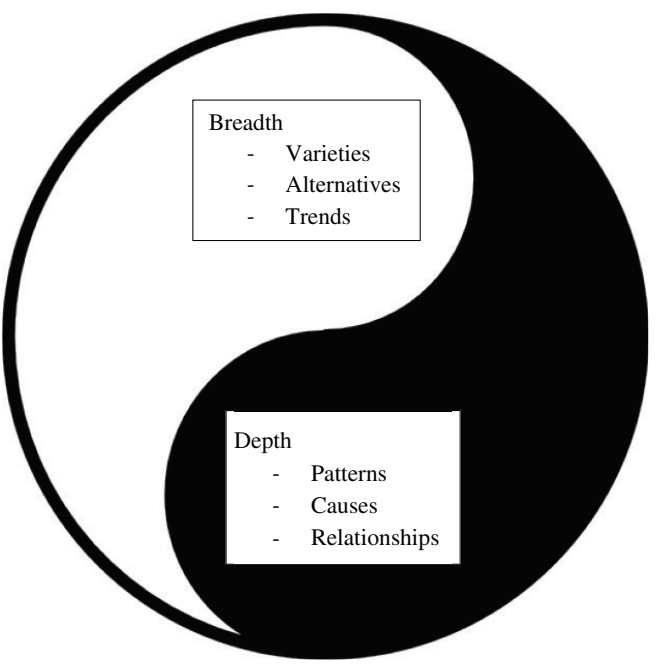

Figure 6: Balancing Depth and Breadth 
This page intentionally left blank 


\section{Chapter}

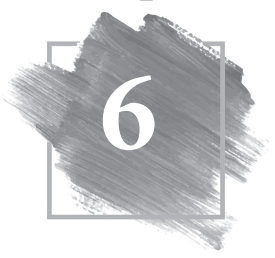

\section{Contribution of Confucianism, Daoism and Buddhism to Modern Oriental Management}

\footnotetext{
Digure 7 shows the contribution of Confucianism, Daoism and Buddhism to modern Oriental management. Managers may adopt a combination 1 of various philosophies in their management styles. For example, they may value the corporate hierarchy, yet they may empower their subordinates and advocate change management. Today's modern Oriental management is a fusion of Oriental philosophies and Western theories.
} 


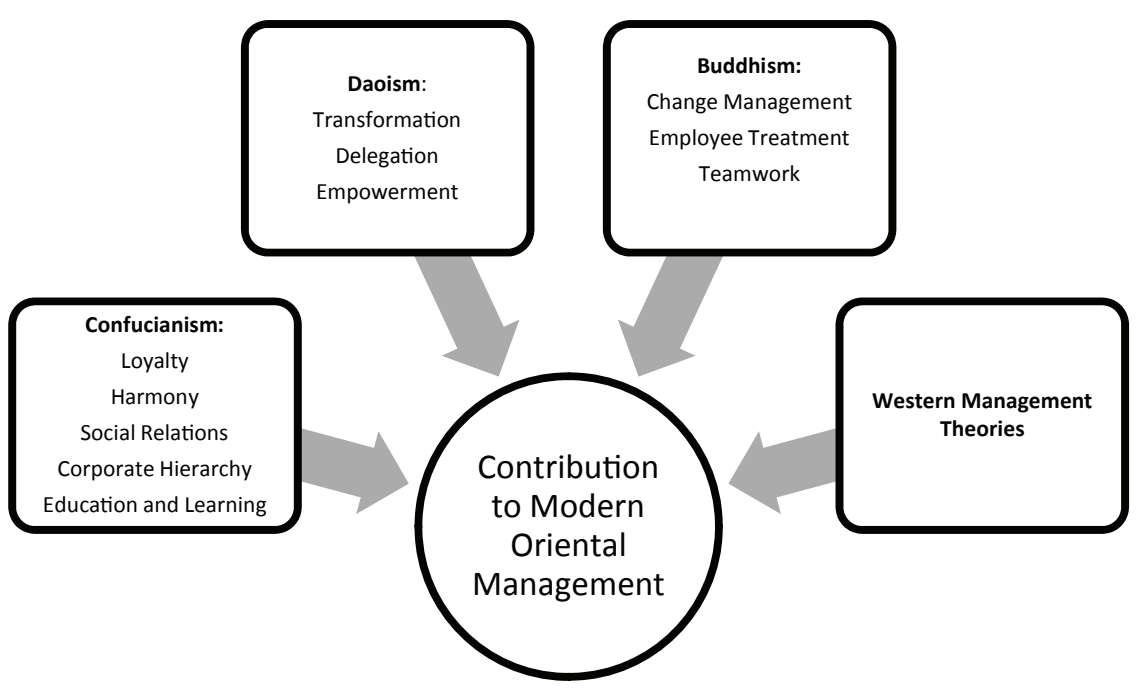

Figure 7: Contribution to Modern Oriental Management

\section{Case of Jack Ma of Alibaba Group}

The Chairman of the Alibaba Group, Jack Ma, is one renowned businessman who has incorporated elements of Confucianism, Daoism, Buddhism and Western management theories into his management style. At Alibaba, the culture of accommodation and transformation, learning and development, teamwork, respect for hierarchy, motivating talents and performance management are all weaved together to form a unique corporate culture.

Jack Ma advocates using Chinese culture as a foundation while adapting Western principles. He believes in providing overall guidance while letting his ground-level managers decide how they would like to run the company. By empowering the managers, they become more motivated and able to make their own decisions rather than relying on him for direction. Increased levels of satisfaction lead to higher employees' loyalty (Wagner \& Harter, 2006). 
It is essential for Jack Ma to balance long-term goal orientation with engagement. Focusing too much on goals will result in shutting out others' opinion, leading to a myopic self-centred view of the organisation. Conversely, too much engagement will result in too many opinions, leading to delays in making decisions (Figure 8).

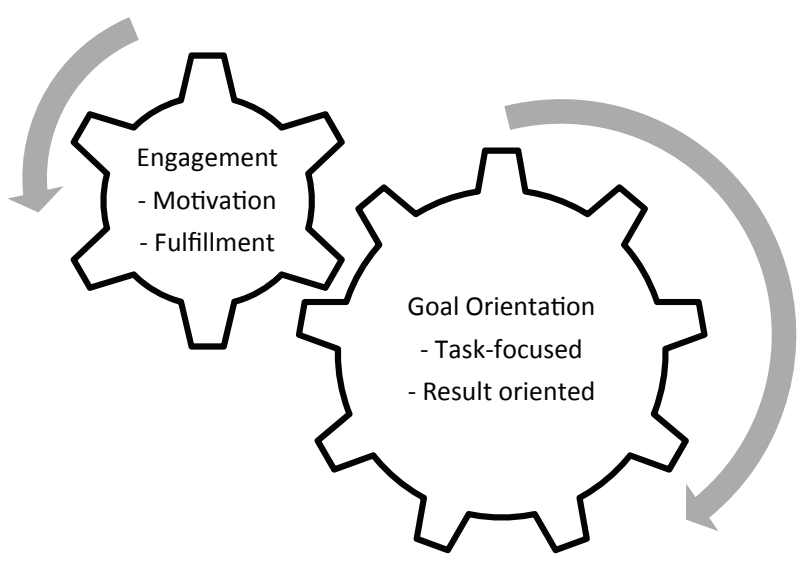

Figure 8: Balancing Long-Term Goals and Engagement 